\title{
Genentech is poised for an anti-cancer breakthrough
}

\author{
Russ Hoyle
}

Ever since the freewheeling G. Kirk Raab was forced to step down three years ago as head of Genentech (S. San Francisco, CA), his successor Arthur D. Levinson has been under pressure to beef up the company's research and development programs and produce exciting new product lines.

Levinson has gotten off to a good start. Genentech, which was bought out by Hoffman-LaRoche (Basel) in 1990, began marketing Rituxin, the only federally approved monoclonal antibody for the treatment of cancer, last November. With the announcement this September that a US Food and Drug Administration (FDA; Rockville, MD) advisory committee voted to approve Genentech's experimental Herceptin monoclonal antibody, Levinson and Genentech are now poised for another impressive therapeutic breakthrough for late-stage treatment of breast cancer. The FDA is expected to approve Herceptin by the end of the year.

For Levinson, the timing could not be more serendipitous. When he took over the company in 1995, what was then known as Her2 was among the hottest new properties in Genentech's pipeline. It was also believed that Levinson's fate would probably depend on how successfully he beefed up Genentech's flagging research programs and brought innovative new pharmaceutical products to market. Under the terms of the buyout, Hoffman-LaRoche, which owns $67 \%$ of Genentech, is due to exercise its option to purchase $100 \%$ of the company next year.

The development of an effective monoclonal antibody targeting the HER2 oncogene, a marker for the fatal spread of lateterm breast cancer, has been a result of determined and exacting scientific research that began on Raab's watch. Under Levinson's leadership, Genentech has also developed a knack for cooperation with the cancer community and a cool capacity for taking advantage of a changing regulatory climate.

As early as the mid-1980s, attempts to use monoclonal antibodies to treat cancer seemed promising. Early efforts to make monoclonal antibodies involved injecting antigens into mice on the theory that the resultant antibodies would block cancerous cell growth. These attempts failed due to the unanticipated fact that bits of protein molecule from the mice acted as antigens in humans, triggering immune responses that destroyed any therapeutic effects.
For the better part of a decade, the excitement over monoclonal therapies cooled. Then researchers figured out how to replace the problematic mouse-contaminated portions of molecules with replacement material from human proteins. Genentech's new "humanized" experimental monoclonal antibody therapy targeted the growth factor receptor gene HER2/neu, which was known to proliferate on the surface of cancerous breast tissue cells in deadly late-stage cases of the disease. The antibody worked by attaching itself to the HER2 receptor, blocking the genetic signals that cause diseased cells to reproduce and in some cases killing off the cancer cells.

The potential market was small, but in dire need. Some 1.6 million American women currently have breast cancer. There are 180,000 new cases in the U.S. each year. Of the roughly 164,000 metastatic cases, some $25-30 \%$ involved overexpression of the HER2 gene. As early as 1995, Genentech was swamped by demand for the highly targeted, yet-to-be-approved new drug and teamed up with patient advocacy groups to design a lottery system to equitably distribute a limited supply of the investigational drug to severely affected patients.

But it wasn't until 1996, less than a year after Levinson had taken the reins from Raab, that Genentech announced favorable results of the initial tests of its experimental therapy. At an April scientific meeting, Genentech clinical researcher Thomas Twadell reported that 5 of 44 women treated with the new antiHER2 antibody alone experienced significant tumor reduction. In combination with other chemotherapy, positive responses occurred in nine out of 36 cases, or $25 \%$ of those treated.

More than a year later, in December 1997, Genentech announced "favorable" preliminary results of phase III clinical trials. Levinson declared that the studies "have shown that the Herceptin monoclonal antibody may result in both slowing the progression of the cancer and increasing the percentage of woman who experience tumor shrinkage." He was careful to add that Herceptin was "not a cure," but emphasized that the encouraging results suggested that "better control of the disease is possible." In short order the company announced that it would file with the FDA for fast track approval of Herceptin, taking advantage of a new law passed by Congress earlier that year.

From that point on, the pace picked up considerably. This past March, Genentech announced a deal with DAKO A/S (Glostrup, Denmark) to develop a diagnostic kit to screen patients for overexpression of the HER2 receptor for FDA approval. In May, the FDA granted fast track status to Herceptin. The fast track application, said Levinson, marked "a massive effort on the part of Genentech, the clinical trial investigators and staff, breast cancer advocates, researchers and the FDA to evaluate this novel treatment as rapidly as possible."

Two weeks later, on May 17, the preliminary data from the phase III clinical trials were reported at the annual meeting of the American Society on Clinical Oncology. They were impressive (Nat. Biotechnol. 16:615, 1998). The randomized, controlled study of 469 women with metastatic breast cancer showed that $28 \%$ of women treated with Herceptin showed no progression of the disease for 7.6 months after treatment began, compared with 4.6 months for chemotherapy alone-a dramatic $65 \%$ increase.

Combining Herceptin with chemotherapy resulted in tumor shrinkage of $50 \%$ or more in $49 \%$ of the patients, compared to $32 \%$ in patients who underwent chemotherapy alone. The results were particularly encouraging in combination with chemotherapy using paclitaxel, a form of taxol. A second study of 222 patients found that $16 \%$ of women, who had been previously treated with conventional chemotherapies, showed major tumor reductions for nine months after using Herceptin alone.

Although last month's favorable recommendation by the FDA's Oncologic Drugs Advisory Committee is not binding, most observers expect the FDA to approve Herceptin for commercialization by November. Right now, the reality is that breast cancer patients who overproduce HER2 can now expect to live some 10 to 12 months after metastasis begins, a horribly rapid progression compared to six or seven years for HER2-normal patients. Genentech has teamed up with the National Cancer Institute to expand its Herceptin access program across the nation and has vowed to produce an "adequate" supply of the drug by this fall anticipating FDA approval.

As anyone familiar with terminal cancer knows, a few extra months of coherent, painfree life is tantamount to the Holy Grail. Barring any surprises, Genentech's Levinson should be credited for showing the pharmaceutical biotechnology industry how to get the job done. 